\title{
Rethinking Humour in the Book of Jonah: Tragic Laughter as Resistance in the Context of Trauma
}

\author{
L. Juliana M. ClaAsSens (STEllenbosch University)
}

\begin{abstract}
Several scholars have identified comedic elements in the book of Jonah. However, underlying these comedic elements are traumatic memories of the devastating violence caused by empires. So the reference to Nineveh is likely to evoke memories of the terrible cruelty performed by the Assyrians, coupled with painful memories of the Babylonian invasion of Jerusalem that saw the destruction of the city and the temple in addition the deportation of thousands of its inhabitants. This article will read the comedic elements in the book of Jonah through Jacqueline Bussie's notion of "tragic laughter." Tragic laughter emerges out of a context of trauma and has the purpose of interrupting a system of oppression, so serving as a form of resistance and protest in the face of the devastating psychological effects of trauma. By transforming tragedy into comedy, tragic laughter plays an important role in fostering hope, so enabling the survival of the human spirit.
\end{abstract}

KEYWORDS: Humour, Tragic Laughter, Jonah, Trauma, Satire, Comedy

\section{A INTRODUCTION}

Several scholars have identified comedic elements in the book of Jonah. So William Whedbee, ${ }^{1}$ Yvonne Sherwood, ${ }^{2}$ and most recently Mark Biddle ${ }^{3}$ have highlighted some of the very funny images in Jonah, such as that of a ship having a nervous breakdown. As Sherwood says it well: "The ship, fearing her wrecking, becomes literally a nervous wreck." And what could be funnier than

* Article submitted: 17 August 2015; accepted: 23 October 2015. To cite: L. Juliana Claassens, "Rethinking Humour in the Book of Jonah: Tragic Laughter as Resistance in the Context of Trauma," Old Testament Essays 28 no. 3 (2015): 655-673. DOI: http://dx.doi.org /10.17159/2312-3621/2015/v28n3a6

1 J. William Whedbee, "Jonah as Joke: A Comedy of Contradiction, Caricature, and Compassion," in The Bible and the Comic Vision (ed. J. William Whedbee; Cambridge: Cambridge University Press, 1998), 191-220.

2 Yvonne Sherwood, "Cross-Currents in the Book of Jonah: Some Jewish and Cultural Midrashim on a Traditional Text," BibInt 6/1 (1998): 49-79.

3 Mark Biddle, A Time to Laugh: Humor in the Bible (Macon, Ga.: Smyth \& Helwys, 2013), 57-72.

4 Sherwood, "Cross-Currents," 50. Cf. also Biddle humorously writes: "The ship said to herself, 'This is pretty bad; I think I may be in trouble."' See Biddle, A Time to Laugh, 60. 
the comedic portrayal of Jonah being ingested, and then regurgitated by a whale? As Whedbee writes: "What a way to deal with a rebel prophet: to give him a lengthy ride in a sea monster that finally vomits him up on dry ground." Moreover, Biddle draws our attention to the hilarious image of converted cows ${ }^{6}$ donned in sackcloth mooing in lament: "The image of cows fasting, clad in sackcloth, sitting on the ash heap, repenting, and praying to God is the very best definition of absurd comic incongruity."7

However, if one takes into consideration the fact that the main plot line of this short story concerns God's planned destruction of Nineveh - a city with 120000 inhabitants and many animals (4:11) who are destined to die in a most brutal fashion as imagined in the book of Nahum (e.g Nah 3:3), one wonders whether there is really anything to laugh about in the book of Jonah.

Moreover, the mere reference to Nineveh would have been enough to cause the hearers of this story to tremble in fear ${ }^{8}$ - victim to the night tremors and anxiety-ridden dreams that are associated with post-traumatic stress ${ }^{9}$ evoked by the memories of the terrible cruelty performed by the ancestors of the very Assyrians of whom we read in Jonah, in addition to the even fresher memories of the widespread carnage that accompanied the city of Jerusalem

5 Whedbee, "Jonah as Joke," 201. Cf. also Sherwood who writes that "in satirical readings the fish's belching is restored to the text as a sign of disgust, a comment on what the fish, and by analogy the critic, can't stomach. The fish, claims Holbert, is literally sick of this man and his false piety and 'it is no wonder that immediately after Jonah shouts 'Deliverance belongs to YHWH!' the big fish throws up." See Sherwood, "Cross-Currents," 51; John C. Holbert, "Deliverance Belongs to YHWH: Satire in the Book of Jonah," JSOT 6 (1981): 74.

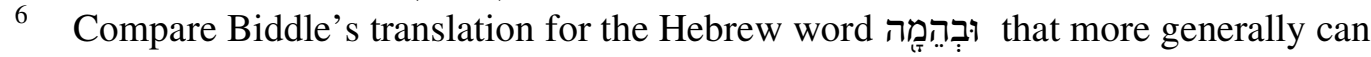
be translated as "beasts," "animals" or indeed also, as "cattle." Cf. also Hans Walter Wolff's heading of his commentary on Jonah 3:3b-10, see Hans Walter Wolff, Obadiah and Jonah (CC; Minneapolis, Minn.: Fortress Press, 1986 [German 1977]), 143.

7 Biddle, A Time to Laugh, 66.

8 The reference to Assyria and its capital Nineveh functions in this instance as a cypher or a symbol in a carefully crafted narrative that typically has been described in terms of a moral story, a parable or a mashal that seeks to communicate a serious message for its intended postexilic audience, whose context is, as I argue in this paper, marked by the trauma of a series of consecutive empires. See Jack M. Sasson, Jonah: A New Translation with Introduction, Commentary, and Interpretation (AB; New York: Doubleday, 1990), 335-336; Janet Howe Gaines, Forgiveness in a Wounded World: Jonah's Dilemma (StBL 5; Atlanta, Ga.: Society of Biblical Literature, 2003), 23-24; Barbara Green, Journeys of Jonah (Collegeville, Minn.: Liturgical Press, 2005), 90-91; 335-337.

9 Judith Herman, Trauma and Recovery: The Aftermath of Violence - From Domestic Abuse to Political Terror (New York: Basic Books, 1997), 34. 
being ransacked by the Babylonians. ${ }^{10}$ One should also not miss the reference to the near shipwreck in the beginning of the story with the sailors justifiably fearing for their lives. That, after all, constitutes another greatly traumatic event. Add to this the near fatal drowning of a man thrown overboard who, in his song of deliverance, describes his encounter with death in terms of having gone down to Sheol (2:2) and one might come to the conclusion there is very little that is funny in the book of Jonah. ${ }^{11}$

Actually, what helps to reconcile these two seemingly contradictory statements, i.e., that the book of Jonah is no laughing matter, and that there is a lot that is humorous in this short book that is included among the minor prophets, is the notion of "tragic laughter." In her award-winning book, The Laughter of the Oppressed, Jacqueline Bussie defines "tragic laughter" as laughter that emerges in a context of trauma, which, as she argues, "interrupts the system and state of oppression, and creatively attests to hope, resistance, and protest in the face of the shattering of language and traditional frameworks of thought and belief." 12

This paper will read the comedic elements in the book of Jonah through this lens of "tragic laughter." I propose that tragic laughter as a heuristic concept may help us better to understand the way humour functions in the story of Jonah particularly when reading this prophetic book as trauma literature that

10 An important premise of this article is that Jonah is to be placed in a postexilic setting. Cf. e.g. Sasson, Jonah, 20-28; Wolff, Obadiah, 76-78; Daniel Smith-Christopher, A Biblical Theology of Exile (Minneapolis, Minn.: Fortress, 2002), 130-135; Gaines, Forgiveness, 24-26. Within the proposed setting of the book of Jonah, the Persian Empire, moreover, has been shown to be no less oppressive than its predecessors. As David Downs writes, for Jonah's post-exilic readers Assyria would not only have symbolised the fearsome empire responsible for destroying the Northern kingdom but also as "a symbol of the foreign powers (now Persian) who still largely controlled Jewish affairs in sixth and fifth centuries." See David Downs, "The Specter of Exile in the Story of Jonah," HBT 31 (2009): 40.

11 Whedbee cites some scholars who dismiss the comic character of the book of Jonah. E.g. Adele Berlin critiques John Miles' characterisation of Jonah as parody that "Jewish tradition regards the Book of Jonah with such reverence that it is read at the afternoon service of the day of Atonement, hardly the appropriate occasion for a parody of the Bible." See Adele Berlin, "A Rejoinder to John A Miles Jr, With Some Observations on the Nature of Prophecy," JQR 66/4 (1976): 227. Cf. also Kenneth Craig who maintains that "the story is too earnest for laughter." Kenneth Craig, $A$ Poetics of Jonah: Art in the Service of Ideology (Macon, Ga.: Mercer University Press, 1999), 143. Whedbee argues that both Berlin and Craig fail "to recognize that comedy and parody can in fact be compelling strategies in the service of religious faith." Rather he proposes that comedy can serve as a powerful vehicle for dealing with some "deadly serious" themes. See Whedbee, "Jonah as Joke," 193.

12 Jacqueline A. Bussie, The Laughter of the Oppressed: Ethical and Theological Resistance in Wiesel, Morrison, and Endo (New York: T\&T Clark, 2007), 4. 
seeks to make sense of the traumatic memories of the exile and its aftermath that had so comprehensively derailed the lives of the people of Judah. ${ }^{13}$

\section{B TRAGIC LAUGHTER}

I first encountered the notion of "tragic laughter" when asked to contribute an article to a special issue of Interpretation on "Laughter as Resistance." 14 In this article, in which I explored the way laughter functions as means of resistance in the book of Job, I found Jacqueline Bussie's notion of "tragic laughter" greatly helpful for understanding the way in which laughter functions as a type of "hidden transcript" (to cite James Scott's designation) ${ }^{15}$ of ordinary people refusing to give into the terrible suffering imposed by their oppressors. In this regard, Bussie maintains that art serves as a creative means of capturing "the perspectives of the marginalized in the absence of political power." As a result, Bussie uses three novels, Elie Wiesel's Gates of the Forest, Toni Morrison's Beloved, and Shusaku Endo's Silence, through which she shows how the laughter of the Jews during the Holocaust, the laughter of African Americans during slavery and the laughter of the persecuted religious minority of Japanese Christians all served the important function of helping ordinary people who find themselves in situations of oppression to survive. ${ }^{16}$

For instance, Bussie shows how tragic laughter plays an important role in the formation of an alternative identity that stands over against that of the oppressors. With reference to two of the characters in the novels she explores, Baby Suggs in Beloved, and Gavriel in Gates of the Forest, Bussie writes how these two characters by refusing to weep but instead choosing to laugh are able to overcome the anguish and despair associated with finding themselves in an

13 There are of course also other themes that have been traditionally explored in terms of Jonah, e.g. Atonement versus Repentance, Universalism verses Particularism, Justice versus Mercy. These themes have been explored elsewhere in commentaries, such as Uriel Simon, Jonah (trans. L. J. Schramm; JPSBC; Philadelphia, Pa.: Jewish Publication Society, 1999), vii-xiii; Terence E. Fretheim, The Message of Jonah (Eugene, Oreg.: Wipf \& Stock, 2000); Howe Gaines, Forgiveness. These are of course all valid interpretations of the book of Jonah, though not the only interpretation. In this article, I propose that by reading the prophetic books as trauma literature, making sense of the ongoing trauma that life under a series of empires brought to Judah, new perspectives emerge.

14 L. Juliana Claassens, "Tragic Laughter: Laughter as Resistance in the Book of Job," Int 69/2 (2015): 143-155.

15 Bussie, Laughter of the Oppressed, 5. Cf. James C. Scott, Domination and the Arts of Resistance: Hidden Transcripts (New Haven: Yale University Press, 1990); James C. Scott, Weapons of the Weak: Everyday Forms of Peasant Resistance (New Haven: Yale University Press, 1985).

16 Bussie, Laughter of the Oppressed, 5. 
oppressive situation. They do this by maintaining a sense of self amidst seemingly futile and dignity-denying circumstances. ${ }^{17}$ According to Bussie:

If oppressors can rob the oppressed of hope, in addition to robbing them of justice, then surely the oppressors have won twice. Laughter allows the oppressed to fight back and interrupt not only the system and state of oppression, but also the despair that oppression strives to inflict on its subjects, by compelling them to reject their narrative of faith and hope. ${ }^{18}$

Two recent theories of laughter are important for understanding this notion of "tragic laughter." First, in what is called the "Relief Theory of Laughter and Humor," Bussie draws on the work of Sigmund Freud and Mikhail Bakhtin to explain the important function of tragic laughter "as a mode of social critique, theological critique, and means of resistance to oppressive systems." According to Bussie, "Freud defines a tendentious joke as one that functions to release repressed feelings of aggression, anger, and criticism toward people or institutions. A tendentious joke is a masked way of saying something forbidden, and getting away with it under the guise of humor."20 Freud writes:

By making our enemy small, inferior, despicable or comic, we achieve in a roundabout way the enjoyment of overcoming him - to which the third person...bears witness by his laughter. Tendentious jokes are especially favored in order to make aggressiveness or criticism possible against persons in exalted positions who claim to exercise authority ... Tendentious jokes are also highly suitable for attacks on the great, the dignified and the mighty, who are protected by internal inhibitions and external circumstances from direct disparagement. $^{21}$

Furthermore, Mikhail Bakhtin focuses on the political implications of humour when he describes carnival laughter's "creative potential to upset the status quo, overcome traditional fears and prohibitions, and empower the disempowered." 22 For Bakhtin laughter thus can be said to hold what Bussie

17 Bussie, Laughter of the Oppressed, 136.

18 Jacqueline A. Bussie, "Laughter as Ethical and Theological Resistance: Leymah

Gbowee, Sarah, and the Hidden Transcript," Int 69/2 (2015): 179.

19 Bussie, Laughter of the Oppressed, 16.

20 Bussie, Laughter of the Oppressed, 14.

21 Sigmund Freud, Jokes and Their Relation to the Unconscious (trans. James Strachey; New York: W.W. Norton, 1960), 103. Cited in Bussie, Laughter of the Oppressed, 14-15.

22 Bussie, Laughter of the Oppressed, 15-16. 
describes as "inversionary power," that is the ability to foster "genuine freedom and decentralize[s] power structures."23

Second, an important aspect of tragic laughter is the paradoxical and incongruous nature of laughter in contexts of trauma. Bussie draws on the "Incongruity Theory of Laughter" in describing the nature and significance of the laughter of the oppressed. She writes that, according to Immanuel Kant, laughter has two main characteristics: (1) "laughter is a reaction to the absurd, to that which defies rational understanding, and (2) laughter arises out of the incongruity between our expectations and a reality that negates those expectations." 24 Moreover, she cites Arthur Schopenhauer who has argued that all laughter is occasioned by paradox:

... [a]ccordingly the phenomenon of laughter always signifies the sudden apprehension of an incongruity between such a conception and the real object thought under it, thus between the abstract and the concrete object of perception. The greater and more unexpected, in the apprehension of the laughter, this incongruity is, the more violent will be his laughter. ${ }^{25}$

This understanding of tragic laughter is particularly helpful when viewing the way humour functions in the book of Jonah. In the following section, it will be shown how, in response to the traumatic memories of the pain and suffering inflicted by the long line of enemy empires that have wreaked havoc in the lives of Israel, the survivors used humour as a means of resistance and protest in the face of the devastating psychological effects of trauma. Kathleen O'Connor argues that trauma quite often leaves its victims numb, confused and unable to put into words what had happened to them. ${ }^{26}$ Moreover, trauma also has been shown to destroy individuals' and groups' traditional thought and belief systems in what Louis Stulman and Hyun Chul Paul Kim call the "collapse of cherished institutions and understandings of life."27 Tragic laughter offers a means of overcoming trauma by contributing to the formation of an

23 Bussie, Laughter of the Oppressed, 16. Bussie notes that Freud does not consider political implications. "Expanding upon Freud, I reimagine laughter as a mode of resistance to and interruption of oppressive systems - a tendentious form of expression that paradoxically masks and reveals an aggressive social critique." See Bussie, Laughter of the Oppressed, 15.

24 Bussie, Laughter of the Oppressed, 13.

25 Arthur Schopenhauer, The World As Will and Idea (vol. 2; London: Forgotten Books, 2013 [repr. 1909]), 271. Cited in Bussie, Laughter of the Oppressed, 13.

26 Kathleen O'Connor further notes how trapped in a "kind of half-life," trauma victims often are "unable to move toward recovery or to flourish as vital human beings." See Kathleen O'Connor, Jeremiah: Pain and Promise (Minneapolis, Minn.: Fortress, 2011), 3-4.

27 Louis Stulman and Hyun Chul Paul Kim, You are My People: An Introduction (Nashville, Tenn.: Abingdon, 2010), 98. 
alternative consciousness that refuses to succumb to the ideology of the oppressors. ${ }^{28}$ By transforming tragedy into comedy, tragic laughter plays an important role in fostering hope, so enabling the survival of the human spirit.

\title{
C LAUGHTER AS RESISTANCE IN THE BOOK OF JONAH
}

Much of the Hebrew Prophets can be characterised as trauma literature. Louis Stulman describes well how the biblical prophets have sought to make sense of the trauma that has disrupted their lives:

\begin{abstract}
Written prophecy is disaster and survival art for communities living through the wreckage of war and captivity. This artefact of terror, this artefact of hope, dares to address the realities of traumatic violence. It refuses to banish memory and close down the senses, as W.G. Sebald suggests post-war nations are inclined to do. It speaks of annihilated worlds and shattered communities, as well as the collapse of cherished institutions and understandings of life. And it will not flatten life into static and singular categories. ${ }^{29}$
\end{abstract}

The book of Jonah has also been shown to be responding to some extent to the trauma of the exile. Ehud Ben Zvi argues that Jonah's intended audience is the literate leadership of postexilic Judah constituting both those who have experienced exile as well as those who have not. Ben Zvi argues that those members of the community who have lived through the exile were forever shaped by the experience of having seen their city and temple, thought to be indestructible, destroyed; of losing their homes and having to live in exile. ${ }^{30}$ This manifestation of second-hand or intergenerational trauma is rightly described by Barbara Green as "a trauma not wholly overcome." 31

In an interesting article titled "The Specter of Exile in the Story of Jonah," David Downs shows how memories of exile seem to haunt the book of

28 Bussie, Laughter of the Oppressed, 152. Bussie explains this idea of a "changed consciousness" in terms of one of the characters in Morrison's novel Beloved, Sixo who by "dancing, singing, taking-not-stealing, plotting escape, and eventually by laughing ... manifests and sustains a changed consciousness, one that is liberated from the white slave owners' ideology."

29 Louis Stulman, "Reading the Bible Through the Lens of Trauma and Art," in Trauma and Traumatization in Individual and Collective Dimensions: Insights from Biblical Studies and Beyond (ed. Eve-Marie Becker, Jan Dochhorn and Else K. Holt; Göttingen: Vandenhoeck \& Ruprecht, 2014), 188. Cf. also the excellent introduction to the Prophets by Stulman and Kim, You are My People.

30 Ehud Ben Zvi, "What's New in Yehud? Some Considerations," in Yahwism after Exile: Perspectives on Religion in the Persian Era (ed. Rainer Albertz and Bob Becking; Assen: Royal Van Gorcum, 2003), 36-37. Green writes: "The Jonah narrative, at least at the surface, clothes itself not so much in dress of 'the exile' as with the garb of earlier times." See Green, Journeys, 42-43.

31 Green, Journeys, 41. 
Jonah. He writes that "while Jonah is not a book about [my emphasis] exile, the traumatic experience of expatriation and captivity casts a spectral shadow across Jonah's narrative." 32 Downs focuses particularly on the way that setting functions in the book of Jonah, showing how a number of exilic motifs manifest themselves with regards to location and more specifically, "re/dislocation.",33

In this regard, the image of Jonah being thrown into the sea is significant. The verb "hurl" (טול) is used four times in ch. 1-God hurls a great wind upon the sea (הטיטיל in 1:4), the sailors hurled the cargo of the ship into the sea

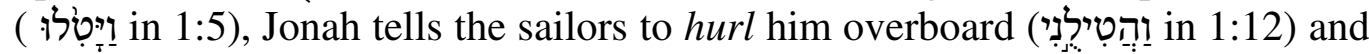

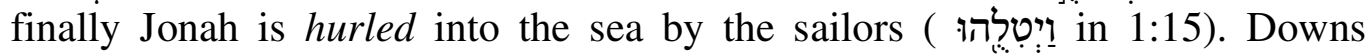
rightly points out that, in the $\mathrm{HB}$, the sea signifies the forces of chaos and conflict. Moreover, the term "hurling" has been shown to function in the prophetic literature as a "metaphor for exile." 34 For instance, in Jer 16:13, Israel is said to

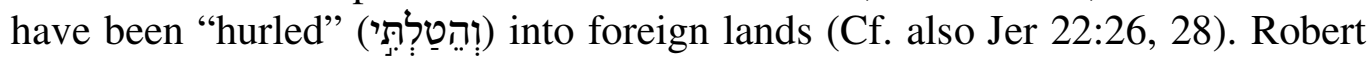
Carroll argues that "hurling" is a violent image that "captures well the aggression inherent in the savage acts which frequently accompanied deportation." $" 35$ It may well be then that, as Downs has argued, "Jonah's dislocation from the security of the ship to the danger of the water is imbued with the language taken from the great crisis in Israel's history, this trope of 'hurling' may be representative of associations with the exile." 36 This is also evident in the reference to Jonah crying to God "out of the belly of Sheol" (Jonah 2:3), which in the case of Isa 5:13-14 has been understood as a metaphor for exile: ${ }^{37}$

Therefore my people go into exile without knowledge;

their nobles are dying of hunger, and their multitude is parched with thirst.

Therefore Sheol has enlarged its appetite and opened its mouth beyond measure;

the nobility of Jerusalem and her multitude go down, her throng and all who exult in her.

Thus, within a context in which memories of exile loom large, laughter in the book of Jonah may serve as a means of coming to terms with the terrifying effects of trauma on the human psyche. So Yvonne Sherwood shows with

32 Downs, "Specter of Exile," 27.

33 Downs, "Specter of Exile," 31.

34 Downs, "Specter of Exile," 34.

35 Robert P. Carroll, "Deportation and Diasporic Discourses in the Prophetic Literature," in Exile: Old Testament, Jewish, and Christian Conceptions (ed. James M. Scott; JSJSup 56; Leiden: Brill, 1997), 65. Cited in Downs, "The Specter of Exile," 34.

36 Downs, "Specter of Exile," 38.

37 Downs, "Specter of Exile," 38. 
reference to Mikhail Bakhtin's notion of carnival that "adds yeast to, ${ }^{38}$ and inflates reality," how carnivalistic elements permeate the book of Jonah. For instance, one sees how "the qiqayon grows to gigantic proportions enough to offer shade to a man, the city Nineveh becomes indeed a great city which takes three days to cross. Moreover, the "abstract idea of 'descent into Sheol' is materialised as descent into a fish's belly." And most importantly, in light of Freud's understanding of the tendentious joke referenced earlier, the objects of fear are ridiculed by means of parody: "The Assyrians, the arch-enemies of Israel, dress their animals in sackcloth in a kind of am dram production of repentance and are described as not knowing their right hand from their left." Indeed, as Sherwood rightly notes, "in carnival, vulgar and sacred language mix - in Jonah the language of being sick collides with the language of praise." 40

Contemplating the notion of laughter as response to traumatic events such as reflected in the book of Jonah, we may identify the following instances of tragic laughter: first, by portraying the fearsome Assyrians, who have come to represent the prime example of the fearsome empire, ${ }^{41}$ in humorous terms, the oppressors' hold on Israel is diminished to some extent. Imagining the enemy as being in a vulnerable position as well, i.e. as potential victims of violence, lamenting, repenting, and quite comically dressing their animals in mourning clothes, serves the function of trivialising and ridiculing the enemy. In this way, the hearer is obtaining some measure of freedom from the fear these mighty foes have managed to exert upon their victims.

The rather surprising image of the terrifying Assyrians repenting, which according to Sherwood could be likened to the fantasy of, what if Berlin, the headquarters of the Nazi regime, were to have a change of heart, ${ }^{42}$ offers a refreshing alternative to the revenge fantasies such as we have seen in the book Nahum. For instance, in Nah 3:19, Judah is imagined to be standing by gloating and clapping their hands over the dead bodies of the inhabitants of Nineveh. The image of the penitent Ninevites that serves the function of resisting and disarming the hold of the empire without resorting to further violence reminds me of one the children's books that I have read to my daughter, namely The Three Little Wolves and the Big Bad Pig. In what already is a great reversal, the

38 Mikhail Bakhtin, Rabalais and His World (Bloomington, Ind.: Indiana University Press, 1984), 278.

39 Sherwood, "Cross-Currents," 63.

40 Sherwood, "Cross-Currents," 63.

41 In her imaginative dialogue between five biblical scholars who have written on Jonah, Barbara Bakke Kaiser has Jack Sasson says that "even though the destruction of Nineveh in 612 BCE lies in the remote past for this exilic writer, Nineveh continued to be a symbol of the evil empire." See Barbara Bakke Kaiser "Five Scholars in the Underbelly of the Dag Gadol: An Aqua-Fantasy," WW 27/2 (2007): 140.

42 Sherwood, "Cross-Currents," 67. 
tables are turned and a vicious Pig repeatedly demolishes the houses built by the three little wolves who just want to play games. In the end, after having built several houses with the strongest steel, barb wire, and cement, which, despite their best efforts could not withstand the Big Bad Pig's attempts to destroy their homes, the three little wolves decided to construct a house out of flowers. The story ends with the Big Bad Pig being seduced by the sweet smell of the fragile and beautiful-to-look-at dwelling, resulting in the now harmless Pig playing games such as piggy-in-the-middle with the wolves instead of violently destroying their home. Imagining an end to destruction in the book of Jonah as evident in the surprise repentance of one of Israel's worst enemies serves as a similar humorous fantasy with a quite serious message.

Second, the comedic portrayal of what Biddle describes as repentant cows $^{43}$ is a good example of tragic laughter. The reminder that the Ninevites have animals serve the function of further humanising the despised Other. As Martha Nussbaum rightly points out, comedy plays a vital role in communicating a sense of a shared human vulnerability that is "common to all, as just a part of being alive, connected to life's joy," and I would also add, to life's sorrow. ${ }^{44}$ Moreover the reference to the lamenting cows who participate in human acts of atonement can be interpreted in terms of recognising a sense of solidarity between humans and animals. In Joel 1:1-20 one finds how the effects of war with its scorched-earth policy that causes widespread famine also causes the cattle, sheep and wild animals to join the humans in lament:

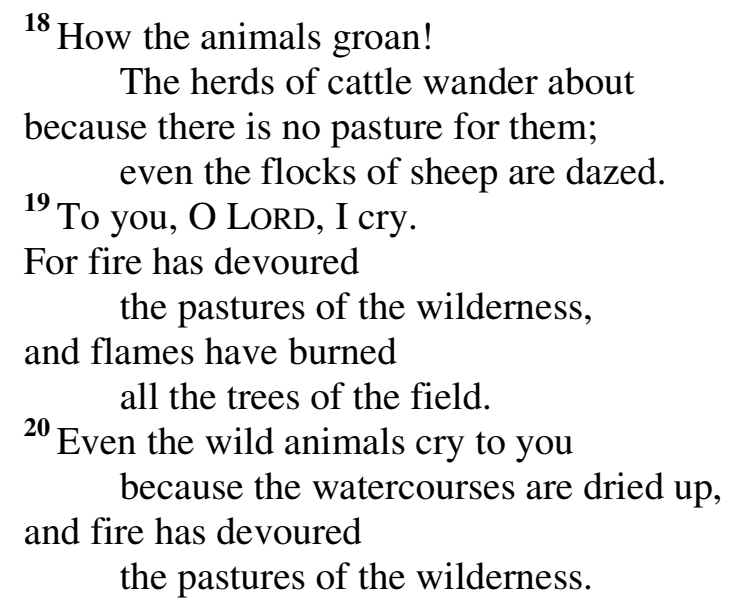

In Jonah, the effects of war on the animals are also recognised when the cows are also crying out for mercy. This reality is also recognised by God as evident from the fact that the reference to the animals forms not only the last word of God's response to Jonah (4:10-11) but of the book as a whole and part of God's reasoning for not destroying Nineveh. The image of repenting cows

43 Biddle, A Time to Laugh, 68-71.

44 Martha Nussbaum, Political Emotions: Why Love Matters for Justice (Cambridge, Mass.: Harvard University Press, 2013), 272. 
may thus be hilarious, but it also captures the tragic reality that in war there is much collateral damage; many innocent victims -human as well as non-human.

Third, in terms of the incongruity theory of laughter, one finds tragic laughter in response to the numerous paradoxes and incongruities that are so prominent in the book of Jonah. One such paradox regards the central theme of theodicy that underlies the book of Jonah. How does one reconcile the confession of the "gracious God and merciful, slow to anger, and abounding in steadfast love, and ready to relent from punishing" of Jonah 4:2 with the traumatic experience of the exile that has been understood as God's punishment? So God is portrayed in the book of Jonah as the subject of a lot of violent imagery hurling the storm on the sea that almost caused the ship to have a nervous


one could also say contemplated) to break up"], appointing (מנה) a worm that

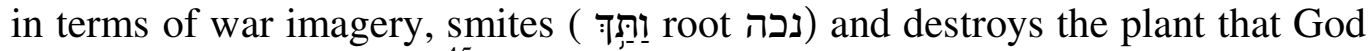
has caused to grow (4:7), ${ }^{45}$ and appointing (מנה) a hot east wind and scorching sun that burn down so hard on Jonah that it threatens his wellbeing and even his life $(4: 8){ }^{46}$

Reminiscent of the confession in Isa 45:7, the God of Jonah is indeed the God who gives shade (protection) but also removes this protection, causing the burning sun to attack the unprotected individual. The subtext is that the same God who is known to be a compassionate God is also the God responsible for the atrocities of cities being destroyed, of lives being lost, of people being taken away into exile. ${ }^{47}$ Bussie captures this paradox well: "On the one hand,

45 Sherwood writes that "YHWH does not send the storm but hurls it (טול), the worm does not nibble at the plant but smites it (נכה) - the worm and the plant are, like God and Jonah, engaged in warfare." See Sherwood, "Cross-Currents," 49.

46 For a great analysis of the carefully crafted internal structures of the book of Jonah cf. Phyllis Trible, Rhetorical Criticism (GBS; Minneapolis, Minn.: Fortress Press, 1994). For her exposition on the role of (מנה) in ch. 4, cf. e.g. pp. 207-213.

47 Yvonne Sherwood describes this paradox as follow: "The God who is Shield, Protector, and Calmer of the Storm is also Nineveh-lover, Job-afflicter, and perverse destroyer of qiqayon plants - God as a gigantic and ultimately unguessable force." See Yvonne Sherwood, A Biblical Text and Its Afterlives: The Survival of Jonah in Western Culture (Cambridge: Cambridge University Press, 2000), 284-285. Moreover, Alan Cooper writes that the dark side of God's capriciousness and unpredictability is "that God's destructive wrath might be just as arbitrary and unconstrained, as in

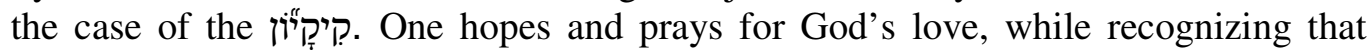
nothing is certain." See Alan Cooper, "In Praise of Divine Caprice: The Significance of the Book of Jonah," in Among the Prophets: Language, Image and Structure in the Prophetic Writings (ed. Philip R. Davies and David J. A. Clines; JSOTSup 144; Sheffield: JSOT Press, 1993), 162. Cf. also Downs who argues that "from Jonah's perspective, YHWH's forgiveness of Nineveh is a manifestation of the 'dark side' of 
we live in the narrative of the promise, love, justice and presence of God, and on the other, we live the narrative of evil, deep suffering, and the absence of God. In plain language, God is good, and life is often horror. God is love, yet horrible things happen to innocent people." 48

Bussie argues that language fails to hold together these two paradoxical truths. However, she proposes that "where language fails us, laughter steps up and steps in to help us express the both/and, paradoxical character of our faith and our lives." ${ }^{49}$ Bussie draws on Mikhail Bakhtin's use of laughter in the context of the absurd, which she proposes serves as a way of holding together "the coexistence of horror and hope, meaninglessness and meaning, terror and faith in regeneration:",50

Bakhtin's discussion of laughter accords with our theological interpretation of laughter as an attempt by the suffering individual to sustain the integrity of both the narrative of faith and the narrative of negativity and to hold both narratives in dialectical tension. Laughter sustains a certain ambivalence, capturing a both-and existential situation in a way that cognitive discourse cannot attain without reductionist tendencies toward either/or. ${ }^{51}$

Fourth, tragic laughter serves the function of opening up the possibility of what Bussie calls "an in-spite-of future" hope. This is a hope that clings to the possibility of things being different in the future even though the current circumstances would have it differently. ${ }^{52}$ So alongside the memories of exile and the violence of past and current empires, one also finds a strong motif of deliverance. The Psalm of Thanksgiving and Praise for Deliverance from Death in Jonah 2:1-9 initially may seem surprising, yet paradoxically when read from the perspective of the book as a whole, it is as Whedbee remarks "curiously appropriate" in light of the fact that the sailors, Jonah, and even those terrible Assyrians get saved throughout the course of the narrative. Actually in a world of war and terror and carnage that forms the backdrop to many of the other Hebrew prophets, the focus on deliverance provides a refreshing perspective, perhaps offering a type of counterworld in which as Whedbee points out, "in keeping with the dominant mode of comedy, nobody gets seriously or permanently hurt; it is a comedy where everyone ultimately is rescued, where various sorts of happy endings prevail." ${ }^{, 53}$ Whedbee concludes that a central tenant of

divine freedom, a violation of Jonah's conception of justice." Downs, "Specter of Exile," 42.

48 Bussie, "Laughter as Ethical," 178.

49 Bussie, "Laughter as Ethical," 178-179.

50 Bussie, Laughter of the Oppressed, 155.

51 Bussie, Laughter of the Oppressed, 155.

52 Bussie, Laughter of the Oppressed, 177.

53 Whedbee, “Jonah as Joke," 216. 
the book of Jonah is that even though "God's creatures, human and animal, might be threatened by evil forces, . . . no one perishes." In fact Whedbee notes that, "apart from the Song of Songs, [Jonah] is the only book in the HB where no one dies."

Or at least, no one dies with the exception of the plant that has been demolished by the divinely appointed worm. So much for using Jonah to propagate eco-theological perspectives. ${ }^{55}$ But perhaps the reference to the plant that gets hurt is a reminder that this counterworld that stands over against the realities of pain and suffering in a world dominated by empires is no paradise. Pain and suffering remains an inevitable part of this world. Wendy Farley describes this reality as a tragic vision of the world which is paradoxical in its very design and permeated by incongruities:

The beauty of the world lies in its variety and diversity. Yet conflict will inevitably arise as the multitude of creatures pursue opposite ends. Tigers will prey on young gazelles. Ice ages will waste entire populations and ecosystems. Agriculture will beat back the jungle. From these conflicts, sorrows and losses emerges the fierce beauty of creation. Sorrow must accompany beauty, but it need not overthrow the poignant loveliness of creation. ${ }^{56}$

Finally, the character of Jonah is also subject to tragic laughter. Many of the comic treatments of the book of Jonah center on a caricature of the prophet who is successful even though he does not want to be. William Whedbee writes that "Jonah paradoxically has enjoyed tremendous success in his mission" and so serves as "a caricature of a prophet, whose parody of famous prophetic words and images intensifies the satirical effect." ${ }^{, 57}$ Similarly, Mark Biddle portrays Jonah as "a prophet who, in the effort to get himself killed, accidentally converted crusty sailors and by means of the sorriest sermon recorded in Scripture, converted cows and even, despite himself, the very Ninevites he had hoped to see destroyed." ${ }^{, 58}$ Biddle continues to elaborate on Jonah's foolishness that is responsible for him refusing to see things God's way. According to Biddle, the humour in the book of Jonah primarily serves the function of ridiculing

\footnotetext{
54 Whedbee, "Jonah as Joke," 216-217.

55 Cf. e.g. Danna Fewell and David Gunn, "Jonah and God: The Book of Jonah," in Narrative in the Hebrew Bible (ed. Danna Fewell and David Gunn; Oxford: Oxford University Press, 1993), 143. Cf. also Sherwood's critique of interpretations that suddenly see Jonah as "a lover of the eco-system and a founder of green theology." Sherwood, "Cross-Currents," 72.

56 Wendy Farley, Tragic Vision and Divine Compassion: A Contemporary Theodicy (Louisville, Ky.: Westminster John Knox, 1990), 60-61.

57 Whedbee, "Jonah as Joke," 211.

58 Biddle, A Time to Laugh, 70.
} 
Jonah whom Biddle characterises as follows: "Someone in this story looks even more foolish that cows at a prayer meeting.,"59

Sherwood warns though that the laughter at Jonah's expense may be just a little bit too hearty. She worries that the increased condemnation of Jonah which underlies many of the comic treatments of the book is rooted in an understanding of the implied author of the book whom she describes as a "liberal-minded pre-Christian Jew . . . a universalist who opposes the arrogance that accompanies chosenness... a twentieth- century liberal academic" and hence "a projection of the critic's own ideology situated behind . . . the text." Most worrisome to her is this line of interpretation's anti-Semitic potential according to which the book of Jonah conceivably could be used in a context of anti-Judaism. ${ }^{61}$ In this regard, Sherwood warns that the humour in the book of Jonah that potentially might have been liberating could actually be used in such a way that it "subverts its potentially liberating effect.",62

Some of the very funny rabbinic interpretations of Jonah, however, depict another way of viewing Jonah. Sherwood draws our attention to the interpretation of Jonah in Pirke de Rabbi Eliezer that tells the story of Jonah the Superhero. In this account, in an elaboration of the surreal, Jonah finds himself in the belly of the whale in a synagogue, a place of study and hence transformation, in which the prophet changes his identity to become a type of "mythological superhero" whose main task becomes capturing the Leviathan, the prime symbol of the forces of chaos and destruction, in preparation of the messianic feast of the righteous. As Sherwood writes: "In his crusade against the real 'baddy,' and his apocalyptic quest, Jonah loses sight of the smallfry Ninevites."63

Sherwood's Jonah becomes representative of all the little people in the original audience imagined in the book of Jonah, but also the scores of everyday individuals since then who are seeking to live amidst the contradictions and ambiguities of life. As Barbara Bakke Kaiser imagines Sherwood to be saying in her imaginative dialogue among five biblical scholars in the belly of the whale:

Jonah is no longer the despised Other, the narrow-minded Jew, champion of justice over mercy. Instead, Jonah becomes Everyman/Everywoman "or baby man, living a brief life between shade/protection and the assault of smiting/striking things, between

59 Biddle, A Time to Laugh, 70.

60 Sherwood, "Cross-Currents," 55-58.

61 Sherwood, "Cross-Currents," 58-59.

62 Sherwood, "Cross-Currents," 61. Cf. also Green, Journeys, 128-129.

63 Sherwood, "Cross-Currents," 65. 
being consumed and being regurgitated, between danger and survival, exile and safety, and life and death. ${ }^{64}$

Viewing the character of Jonah through the lens of tragic laughter, we see a comic hero who fights against the forces of chaos - whose response to God in ch. 4, which incidentally precisely matches God's response in the number of words used (39), ${ }^{65}$ speaks a word of truth and reminds God that God indeed $i s$ and thus also ought to be a "gracious God and merciful, slow to anger, and abounding in steadfast love, and ready to relent from punishing., Citing the Mekilta's definition of the perfect prophet who, as for instance, Jeremiah in Lam 3:42 declared: "We have transgressed and rebelled; You have not forgiven," Sherwood writes that "the perfect prophet . . . is like the rabbis themselves, who, from a position within the tradition, resist, play with and challenge the sacred texts." 67

Perhaps Jonah's refusal to speak a word of judgment against the Ninevites in the first instance could be seen as an act of bravery; a sign of an individual and a people who is tired of the bloodshed and carnage that comes with the violent overthrowing of cities. At the very least, the book of Jonah's overturning of God's violent intentions of overturning Nineveh ${ }^{68}$ offers a sharp contrast with the book of Nahum's revenge fantasies steeped in violence and bloodshed - the remarkable counter reality that "no one dies in Jonah" realising, according to Whedbee, "the fragile hope of the 'who knows?' spoken by an anxious king."69

64 Sherwood, Biblical Text, 280 (quoted in Kaiser, "Five Scholars," 146).

65 Kaiser, "Five Scholars," 145.

66 Whedbee describes Jonah as a "rebel with a cause, who becomes both comic hero and comic victim: a hero in the sense that he is willing to rebel against God to follow out his own conviction; also a victim who becomes manipulated by divine power and voluntary offers himself up to appease the God whom he fears but disobeys ..." See Whedbee, "Jonah as Joke," 200.

67 Sherwood, "Cross-Currents," 67.

68 Cf. Sherwood's discussion of the verb הפך (Jon 3:4) that also can mean "to overthrow" and which according to Rashi is understood that "God strategically uses a world about turning around that can itself be turned around and can speak simultaneously of forgiveness and disaster." Sherwood furthermore points out that "this word of overturning just keeps on turning: if one reads the book of Nahum, which the Septuagint conveniently places after Jonah, one finds a graphic description of how the reversal of the prophecy is itself reversed." See Sherwood, "Cross-Currents," 70.

69 Whedbee, "Jonah as Joke," 220. Cf. also Sherwood who argues that "Nineveh' is a place where the world is nonsensically - and discomfortingly re-sorted, and is more of a wish-inversion than a wish-fulfilment place." See Sherwood, Biblical Text, 260. 


\section{CONCLUSION}

According to Louis Stulman, "prophetic art provides at-risk communities a lens of hope, which survivors can see through and beyond their suffering." He calls the Hebrew Prophets "meaning making literature" that constitutes "a meditation on the horror of war and the audacity of hope. The two - atrocity and hope - are inseparable. ${ }^{, 70}$ In this regard, the comedic elements found in the book of Jonah can be understood as a way of making sense of and transcending the traumatic memories of the exile. Indeed, as Roy Eckardt has argued: "Where there is humor, there is hope; where there is hope, there is humor."

This notion is powerfully expressed in Toni Morisson's novel Beloved. Baby Suggs, who has been earlier in the novel a prime example of tragic laughter leading others to laugh and dance and sing in an important expression of their humanity over against a system that sought to dehumanise them in every way ${ }^{72}$ towards the end of her life could no longer, as Bussie points out, "sustain[ing] this impossible fusion of the memory of hope and the memory of horror." ${ }^{73}$ When it becomes too difficult for Baby Suggs to continue to affirm the possibly of hope, her laughter ends; she stops speaking and retires to bed to contemplate color. Bussie describes Baby Suggs' inability to laugh as follow:

Baby's refusal to laugh signals that she no longer experiences paradox and incongruity. She does not laugh because she no longer feels the both-and character of existence and the in-spite of character of the life of faith. The narrative very sympathetically portrays Baby as someone who can no longer continue the struggle of laughter. ${ }^{74}$

Viewing the comedic elements through the lens of tragic laughter helps us to appreciate just how important it may have been for Israel to hold on to humour in order to survive. In her study on humour in the Holocaust, Chaya Ostrower writes that in the ghettos and camps during the Holocaust, "laughter

70 Stulman, "Reading," 188.

71 Roy Eckardt, "Divine Incongruity: Comedy and Tragedy in a Post-Holocaust World," ThTo 48/4 (1992): 411.

72 Bussie writes how by calling on people to laugh and dance, Baby Suggs encouraged "the people to rediscover themselves as lovable, beautiful, and chosen." See Bussie, Laughter of the Oppressed, 133. As Bussie describes Baby Suggs's laughter: "By laughing, Baby creatively brings to consciousness a potential narrative of celebration, self-affirmation, love, hope, protest - a narrative of hope deliberately made inaccessible to African Americans by whites." See Bussie, Laughter of the Oppressed, 137.

73 Bussie, Laughter of the Oppressed, 140.

74 Bussie, Laughter of the Oppressed, 140. 
was a form of rebellion against reality." who describes the role of humour in her own survival:

This was the integral part of our inner, mental struggle for our human identity, the fact that we could still laugh at things...Humor was an integral part of our spiritual resistance. And this spiritual resistance was the pre-condition for a desire to live. . ${ }^{76}$

While one could say that there is nothing funny about the book of Jonah, from the examples cited above it is evident that laughing is a necessary response for a people seeking to stand up out of the ashes and debris left behind by enemy empires. In the spirit of Jonah's open-ended ending, Roy Eckardt's compelling quote forms a fitting conclusion to this paper:

The underdogs, the fools, the clowns, the jesters, the children keep on dancing and singing and making jokes against every incongruity and against every mystery. There is no other ending, there is not ending at all. There is present only, blessedly, an openness to the future. $^{77}$

\section{BIBLIOGRAPHY}

Bakhtin, Mikhail. Rabalais and His World. Bloomington: Indiana University Press, 1984.

Berlin, Adele. "A Rejoinder to John A Miles Jr, with Some Observations on the Nature of Prophecy." The Jewish Quarterly Review 66/4 (1976): 227-235.

Biddle, Mark. A Time to Laugh: Humor in the Bible. Macon, Ga.: Smyth \& Helwys, 2013.

Bussie, Jacqueline A. The Laughter of the Oppressed: Ethical and Theological Resistance in Wiesel, Morrison, and Endo. New York: T\&T Clark, 2007. "Laughter as Ethical and Theological Resistance: Leymah Gbowee, Sarah, and the Hidden Transcript." in Interpretation: A Journal of Bible and Theology 69/2 (2015), 169-182.

Carroll, Robert P. "Deportation and Diasporic Discourses in the Prophetic Literature." Pages 63-85 in Exile: Old Testament, Jewish, and Christian Conceptions. Edited by James M. Scott. Supplements to the Journal for the Study of Judaism in the Persian, Hellenistic, and Roman Periods 56. Leiden: Brill, 1997.

75 Chaya Ostrower, "Humor as a Defense Mechanism during the Holocaust," Int 69/2 (2015): 184.

76 Cited in Ostrower, "Humor," 183. Cf. also Sarah Blacher Cohen who describes Jewish humor as "a principal source of salvation." She argues that "by laughing at their dire circumstances, Jews have been able to liberate themselves from them. Their humor has been a balance to counter external adversity and internal sadness." See Sarah Blacher Cohen, cited in Jason Kalman, "Heckling the Divine: Woody Allen, the Book of Job, and Jewish Theology after the Holocaust," in Jews and Humor (ed. Leonard J. Greenspoon; West Lafayette, Ind.: Purdue University Press, 2011), 177.

77 Eckardt, "Divine Incongruity," 412. 
Claassens, L. Juliana. "Tragic Laughter: Laughter as Resistance in the Book of Job." Interpretation: A Journal of Bible and Theology 69/2 (2015): 143-155.

Cooper, Alan. "In Praise of Divine Caprice: The Significance of the Book of Jonah." Pages 144-163 in Among the Prophets: Language, Image and Structure in the Prophetic Writings. Edited by Philip R. Davies and David J. A. Clines. Journal for the Study of the Old Testament: Supplement Series 144. Sheffield: JSOT Press, 1993.

Craig, Kenneth. A Poetics of Jonah: Art in the Service of Ideology. Macon, Ga.: Mercer University Press, 1999.

Downs, David. "The Specter of Exile in the Story of Jonah." Horizons in Biblical Theology 31 (2009): 27-44.

Eckardt, Roy. "Divine Incongruity: Comedy and Tragedy in a Post-Holocaust World." Theology Today 48/4 (1992): 399-412.

Farley, Wendy. Tragic Vision and Divine Compassion: A Contemporary Theodicy. Louisville, Ky.: Westminster John Knox, 1990.

Fewell, Danna and David Gunn. "Jonah and God: The Book of Jonah." Pages 129146 in Narrative in the Hebrew Bible. Edited by Danna Fewell and David Gunn. Oxford: Oxford University Press, 1993.

Fretheim, Terence E. The Message of Jonah. Eugene, Oreg.: Wipf \& Stock, 2000.

Freud, Sigmund. Jokes and Their Relation to the Unconscious. Translated by J. Strachey. New York: W.W. Norton, 1960.

Green, Barbara. Journeys of Jonah. Collegeville, Minn.: Liturgical Press, 2005.

Herman, Judith. Trauma and Recovery: The Aftermath of Violence - From Domestic Abuse to Political Terror. New York: Basic Books, 1997.

Holbert, John C. "Deliverance Belongs to YHWH: Satire in the Book of Jonah." Journal for the Study of the Old Testament 6 (1981):59-81.

Howe Gaines, Janet. Forgiveness in a Wounded World: Jonah's Dilemma. Studies in Biblical Literature 5. Atlanta, Ga.: Society of Biblical Literature, 2003.

Kaiser, Barbara Bakke. "Five Scholars in the Underbelly of the Dag Gadol: An AquaFantasy." Word and World 27/2 (2007): 135-148.

Kalman, Jason. "Heckling the Divine: Woody Allen, the Book of Job, and Jewish Theology after the Holocaust." Pages 175-194 in Jews and Humor. Edited by Leonard J. Greenspoon. West Lafayette, Ind.: Purdue University Press, 2011.

Nussbaum, Martha. Political Emotions: Why Love Matters for Justice. Cambridge, Mass.: Harvard University Press, 2013.

O’Connor, Kathleen. Jeremiah: Pain and Promise. Minneapolis, Minn.: Fortress, 2011.

Ostrower, Chaya. "Humor as a Defense Mechanism during the Holocaust." Interpretation: A Journal of Bible and Theology 69/2 (2015): 183-195.

Sasson, Jack M. Jonah: A New Translation with Introduction, Commentary, and Interpretation. Anchor Bible. New York: Doubleday, 1990.

Schopenhauer, Arthur. The World As Will and Idea. Volume 2. London: Forgotten Books, 2013 [repr. 1909].

Scott, James C. Weapons of the Weak: Everyday Forms of Peasant Resistance. New Haven: Yale University Press, 1985. . Domination and the Arts of Resistance: Hidden Transcripts. New Haven: Yale University Press, 1990. 
Sherwood, Yvonne. "Cross-Currents in the Book of Jonah: Some Jewish and Cultural Midrashim on a Traditional Text." Biblical Interpretation 6/1 (1998): 49-79. . A Biblical Text and Its Afterlives: The Survival of Jonah in Western Culture. Cambridge: Cambridge University Press, 2000.

Simon, Uriel. Jonah. The Jewish Publication Society Bible Commentary. Trans. Lenn J. Schramm. Philadelphia, Pa.: Jewish Publication Society, 1999.

Smith-Christopher, Daniel. A Biblical Theology of Exile. Minneapolis, Minn.: Fortress, 2002.

Stulman, Louis. "Reading the Bible Through the Lens of Trauma and Art." Pages 177-192 in Trauma and Traumatization in Individual and Collective Dimensions: Insights from Biblical Studies and Beyond. Edited by Eve-Marie Becker, Jan Dochhorn and Else K. Holt. Göttingen: Vandenhoeck \& Ruprecht, 2014.

Stulman, Louis and Hyun Chul Paul Kim. You are My People: An Introduction. Nashville, Tenn.: Abingdon, 2010.

Trible, Phyllis. Rhetorical Criticism. Guides to Biblical Scholarship. Minneapolis, Minn.: Fortress, 1994.

Whedbee, J. William. "Jonah as Joke: A Comedy of Contradiction, Caricature, and Compassion." Pages 191-220 in The Bible and the Comic Vision. Edited by J. William Whedbee. Cambridge: Cambridge University Press, 1998.

Wolff, Hans Walter. Obadiah and Jonah. Continental Commentaries. Minneapolis, MN: Fortress, 1991.

Zvi, Ehud Ben. "What's New in Yehud? Some Considerations." Pages 36-37 in Yahwism after Exile: Perspectives on Religion in the Persian Era. Edited by Rainer Albertz and Bob Becking. Assen: Royal Van Gorcum, 2003.

Juliana M. Claassens, Professor of Old Testament, Department of Old and New Testament, Faculty of Theology, Stellenbosch University, Stellenbosch, South Africa.Email: jclaassens@sun.ac.za. 